\title{
A comparative study of phytoconstituents and antibacterial activity of in vitro derived materials of four Passiflora species
}

\author{
MARIELA J. SIMÃ̃ ${ }^{1}$, THIAGO J.S. BARBOZA ${ }^{1}$, MARCELA G. VIANNA ${ }^{1}$, RENATA GARCIA ${ }^{1}$, \\ ELISABETH MANSUR ${ }^{1}$, ANA CLAUDIA P.R. IGNACIO ${ }^{2}$ and GEORGIA PACHECO ${ }^{1}$ \\ ${ }^{1}$ Núcleo de Biotecnologia Vegetal, Universidade do Estado do Rio de Janeiro, Rua São Francisco Xavier, \\ 524, Pavilhão Haroldo Lisboa da Cunha, sala 505, 20550-013 Rio de Janeiro, RJ, Brazil \\ ${ }^{2}$ Departamento de Microbiologia, Imunologia e Parasitologia, Faculdade de Ciências Médicas, Universidade do \\ Estado do Rio de Janeiro, Boulevard 28 de Setembro, 87, fundos, $3^{\circ}$ andar, 20551-030 Rio de Janeiro, RJ, Brazil
}

Manuscript received on October 10, 2017; accepted for publication on January 3, 2018

\begin{abstract}
Passiflora species are well known for their common use in popular medicine for the treatment of several diseases, such as insomnia, anxiety, and hysteria, in addition to their anti-inflammatory, antioxidant, analgesic and antibacterial potential. However, few data about the chemical composition and the medicinal potential of in vitro derived materials are available. Therefore, the goal of this work was to compare, for the first time, the phytoconstituents of in vitro derived materials of four Passiflora species, and evaluate the antibacterial potential of their extracts against $20 \mathrm{Gram}$-positive and negative strains. Chromatographic analysis indicated the presence of saponins in roots extracts from all studied species, whereas leaf extracts presented both saponins and flavonoids. Extracts from leaves and roots of $P$. alata and $P$. foetida exhibited a selective inhibitory activity against $B$. thuringiensis and $S$. pyogenes, which might be related to the presence of a high concentration of secondary metabolites, including flavonoids and saponins.
\end{abstract}

Key words: antibacterial, chromatography, flavonoids, Passiflora, saponins.

\section{INTRODUCTION}

Bacteria, fungi, viruses and nematodes have been recognized as the main causes of human and animal infections in tropical and subtropical countries. However, the indiscriminate use of synthetic antimicrobial drugs is leading to an increasing number of multiple drug resistance microorganisms, therefore directing studies towards the discovery of new antimicrobials (Bax et al. 2000). Since medicinal plants may constitute alternative sources

Correspondence to: Georgia Pacheco

E-mail: georgiappacheco@gmail.com of new, natural antimicrobial agents, considerable efforts have been made to investigate the potential of bioactive compounds for the treatment of several infectious diseases (Pan et al. 2009).

The genus Passiflora is the largest and more diverse of the family Passifloraceae, comprising more than 560 species of vines, lianas, trees, and shrubs, commonly used for their fruits and derivatives, and as ornamental and medicinal plants (Ulmer and MacDougal 2004). Leaves, fruits and roots of Passiflora species are traditionally used in several countries for the treatment of insomnia, anxiety and irritability (Dhawan et al. 2004). 
Pharmacological studies carried out in the last 20 years reported distinct biological activities in the genus, including diuretic, anxiolytic, antiinflammatory, antioxidant, analgesic, antiviral, and antihyperglycemic (Montefusco-Pereira et al. 2013, Colomeu et al. 2014), as well as antibacterial activity (Bendini et al. 2006, Mohanasundari et al. 2007, Ripa et al. 2009, Baby et al. 2010, Ingale and Hivrale 2010, Ramaiya et al. 2014, Razia et al. 2014, Subramani et al. 2014). These pharmacological activities have been associated to the presence of alkaloids, flavonoids, saponins, cyanogenic compounds, essential oils, and carotenoids (Dhawan et al. 2004, Gosmann et al. 2011).

In this work, we compared the phytochemical composition and antibacterial potential of four Passiflora species. Passiflora alata and P. foetida belong to the subgenus Passiflora, and are widely used in folk medicine. Passiflora alata is one of the commercially exploited passionfruit, and is present as an official drug in the Brazilian Pharmacopoeia (2010), in addition to its use in phytopharmaceutical preparations due to its sedative and anxiolytic properties. Passiflora foetida is a wild species commonly used for the treatment of hysteria, asthma and skin diseases with inflammation (Dhawan et al. 2004). Passiflora suberosa and P. pohlii are wild species from the subgenus Decaloba, which have important agronomic potential due to their tolerance to virus, fungi, and soil-borne pathogens that cause damages to the passionfruit culture (Gardner 1989, Junqueira et al. 2005). These species are also used as ornamental plants, due to the small size of their fruits and flowers (Ulmer and MacDougal 2004). Leaves of $P$. suberosa are commonly used as a sedative and to treat hypertension, diabetes, and skin diseases (Miller 1998). Although there are no reports on the use of $P$. pohlii in folk medicine, Simão et al. (2016) recently described a high antioxidant potential of its roots.
The over-exploitation of natural resources, caused by the great demand for supplying high-value phytochemicals, as well as the problems associated to seasonal variations and other environmental factors, constitute important limitations to the use of medicinal plants. Considering this, biotechnological methods, including plant cell and tissue cultures, provide alternative tools for largescale production of secondary metabolites (Wilson and Roberts 2012). However, in spite of the well known medicinal potential of Passiflora species, only a few data about the chemical composition and pharmacological activities of in vitro derived materials of these species are available (Antognoni et al. 2007, Fraccaroli et al. 2008, Lugato et al. 2014, Simão et al. 2016). Therefore, the aim of this work was to investigate the presence of flavonoids and saponins, and compare the antibacterial activity of extracts from leaves and roots excised from in vitro-grown plants of four Passiflora species ( $P$. alata, P. pohlii, P. suberosa and P. foetida) against different bacterial strains.

\section{MATERIALS AND METHODS}

PLANT MATERIAL AND TISSUE CULTURE CONDITIONS

In vitro-grown plants of $P$. alata, $P$. foetida, P. pohlii and $P$. suberosa, derived from seed germination (Garcia et al. 2011, Pacheco et al. 2012, Merhy et al. 2014), and maintained by bimonthly subcultures of nodal segments on solidified $1 / 2$ MSM medium (Monteiro et al. 2000), supplemented with $1.5 \%$ sucrose, and solidified with $0.7 \%$ agar (Merck) were used as sources of plant materials for extract preparation. Cultures were maintained in a growth chamber at $25 \pm 2{ }^{\circ} \mathrm{C}$, under a $16 \mathrm{~h}$ photoperiod, using a total irradiance of $46 \mu \mathrm{mol} \mathrm{m}{ }^{-2} \mathrm{~s}^{-1}$ provided by cool-white fluorescent lamps. 


\section{EXTRACT PREPARATION}

Extracts from dry leaves and roots excised from in vitro-grown plants were prepared separately, using $40 \%$ ethanol under reflux (1:10, plant:solvent, $\mathrm{w} / \mathrm{v})$ for one hour $(1 \mathrm{~h})$, as described by Birk et al. (2005). For the evaluation of antibacterial activity, $50 \mathrm{mg}$ of the extracts were solubilized in $200 \mathrm{~mL}$ of dimethyl sulfoxide (DMSO). The extracts $(10 \mathrm{mg}$ ) were also resuspended in methanol for Thin Layer Chromatography (TLC) analysis.

\section{TLC ANALYSIS}

The TLC analysis was carried out as described by Simão et al. (2016). Each sample was directly applied on silica gel-coated TLC aluminum plates (Si gel $60 \mathrm{UV}_{254 \mathrm{~nm}}$, Marcherey-Nagel, 20x20 cm plates).

For flavonoid analysis, the mobile phase was prepared according to Wagner and Bladt (2001), using AcOEt:formic acid:AcOH: $\mathrm{H}_{2} \mathrm{O}$ (100:11:11:26, v/v). The plate was sprayed using $1 \%$ methanolic solution of diphenylboryloxyethylamine (Sigma Aldrich ${ }^{\circledR}$ ), followed by $5 \%$ (w/v) PEG 4000 (Natural Product Reagent-polyethyleneglycol) as color reagents. Spots were observed under UV (365 nm).

The saponins analysis was carried out with $\mathrm{CHCl}_{3}: \mathrm{AcOH}: \mathrm{MeOH}: \mathrm{H}_{2} \mathrm{O}(60: 32: 12: 8, \mathrm{v} / \mathrm{v})$ as the mobile phase (Wagner and Bladt 2001). TLC plates were then visualized using anisaldehyde- $\mathrm{H}_{2} \mathrm{SO}_{4}$ before heating $\left(100^{\circ} \mathrm{C}\right)$ for $5-10 \mathrm{~min}$.

\section{ANTIBACTERIAL ASSAY}

The antibacterial potential of Passiflora extracts was evaluated by the agar dilution method (macrodilution) described by Soberón et al. (2007) with modifications (Barboza et al. 2015). An aliquot of the extracts was solubilized in $20 \mathrm{~mL}$ of pre-warmed Mueller-Hinton Agar (MHA, Oxoid, Ltda.), obtaining the test concentrations of 500 and $1000 \mu \mathrm{g} \mathrm{mL}{ }^{-1}$. The final content was poured into sterile Petri dishes. After the solidification of the medium, $2 \mu \mathrm{L}$ of each bacterial suspension previously grown in Mueller-Hinton Broth (MHB, Oxoid, Ltda.) at $37^{\circ} \mathrm{C}$ for $18 \mathrm{~h}$, were cultivated in duplicate. After $24 \mathrm{~h}$ of incubation at $37^{\circ} \mathrm{C}$, the growth of the colonies was observed and compared to the growth of the control plates containing MHA without extracts (positive control) or with $0.5 \%$ DMSO (negative control). The experiments were repeated three times for each plant material.

Twenty bacterial strains, encompassing Gram-positive and Gram-negative were evaluated (Table I). All the tested strains were obtained from the American Type Culture Collection (ATCC, Rockville, MD, USA) and from the collection of the Department of Microbiology, Immunology, and Parasitology, from the Rio de Janeiro State University.

The evaluation of the minimum inhibitory concentration (MIC), minimum bactericidal concentration (MBC), and the inhibitory concentration of $50 \%$ of the population $\left(\mathrm{IC}_{50}\right)$ were determined by the dilution method in 96well plates. For these assays, only the strains that showed inhibition of growth by the macrodilution method were used.

The bacterial suspensions, adjusted to 0.5 on the McFarland scale, were cultured on MHB at $37{ }^{\circ} \mathrm{C}$ for $18 \mathrm{~h}$, and then adjusted to 0.14 of optic density at $580 \mathrm{~nm}$. The suspensions $(100 \mu \mathrm{L})$ were cultured in 96-well plates in the presence of different concentrations $\left(100-1500 \mu \mathrm{g} \mathrm{mL}^{-1}\right)$ of the extracts $(100 \mu \mathrm{L})$ for $18 \mathrm{~h}$, in quadruplicates. After the incubation period, an aliquot of $2 \mu \mathrm{L}$ of each well was plated onto MHA medium and grown for $18 \mathrm{~h}$ at $37^{\circ} \mathrm{C}$ for proof of the MBC. The plates were analyzed in the microplate reader at $492 \mathrm{~nm}$ and the absorbances were used to measure the MIC and calculate the $\mathrm{IC}_{50}$ by non-linear regression in the GraphPad Prism ${ }^{\circledR}$.

To eliminate the possible influence of color of the extracts, three wells containing only the 
TABLE I

Bacterial strains used for the evaluation of antibacterial activity of different in vitro derived materials of Passiflora species.

\begin{tabular}{|c|c|c|}
\hline & Species & Strains \\
\hline \multirow{6}{*}{ Gram-positive } & Bacillus thuringiensis & (ATCC 33679) \\
\hline & Enterococcus faecalis & $(29212)$ \\
\hline & Staphylococcus aureus & (ATCC 25923) \\
\hline & Staphylococcus simulans & (ATCC 27851) \\
\hline & Staphylococcus saprophyticus & (ATCC 15305) \\
\hline & Streptococcus pyogenes & (ATCC 8668) \\
\hline \multirow{14}{*}{ Gram-negative } & Aeromonas caviae & (ATCC 15468) \\
\hline & Aeromonas hydrophila & (ATCC 7966) \\
\hline & Citrobacter freundii & (ATCC 12241) \\
\hline & Escherichia coli & $(17-2)$ \\
\hline & Escherichia coli & (ATCC 25922) \\
\hline & Escherichia coli & (ATCC 35218) \\
\hline & Escherichia coli $\mathrm{K}-12$ & (HB 101) \\
\hline & Escherichia coli K-12 & (C600) \\
\hline & Enteroaggregative $E$. coli & (EAEC 042) \\
\hline & Klebsiella pneumoniae & (ATCC 700603) \\
\hline & Pseudomonas aeruginosa & (ATCC 27853) \\
\hline & Salmonella typhimurium & $(\mathrm{C} 20)$ \\
\hline & Serratia marcescens & $(7145)$ \\
\hline & Shigella sonnei & (ATCC 25931) \\
\hline
\end{tabular}

extracts at different concentrations, without bacterial suspensions, were analyzed in each assay. The mean value of each triplicate was discounted of the absorbance values for $\mathrm{MIC}$ and $\mathrm{IC}_{50}$.

The experimental controls used were the Mueller-Hinton medium without extracts (positive control) and the same medium supplemented with $0.5 \%$ DMSO (negative control). The experiments were repeated four times and all the materials and culture media were previously sterilized at $121{ }^{\circ} \mathrm{C}$ for 20 minutes.

\section{RESULTS AND DISCUSSION}

Biotechnological approaches are often employed for the stable or increased production of secondary metabolites, without the interference of external factors (Wilson and Roberts 2012). In this work, we investigated the presence of flavonoids and saponins and compared the antibacterial potential of roots and leaves from in vitro-grown plants of four Passiflora species.

The genus Passiflora is a unique source of several phytochemicals, including alkaloids, flavonoids, saponins, essential oils and carotenoids, as well as minerals, fibers and vitamins, which are already explored for human use. The TLC analysis presented here using both NP/ PEG 4000 and anisaldehyde- $\mathrm{H}_{2} \mathrm{SO}_{4}$ as color reagents revealed the presence of flavonoids and saponins in leaf and root extracts from in vitro-grown plants of the four Passiflora species studied.

Characteristic flavonoid fluorescent spots were only observed in leaf extracts. However, each extract presented a distinct chromatographic profile, with different flavonoid-related spots. Extracts from leaves of $P$. pohlii and $P$. foetida displayed fluorescent yellow spots $\left(\mathrm{R}_{\mathrm{F}}=0.35\right.$ 
and 0.43 , respectively), whereas $P$. alata extracts showed major yellow $\left(\mathrm{R}_{\mathrm{F}}=0.42\right)$ and orange $\left(\mathrm{R}_{\mathrm{F}}=\right.$ $0.38)$ spots. Leaves of $P$. suberosa presented three pale orange $\left(\mathrm{R}_{\mathrm{F}}=0.28,0.40\right.$ and 0.63$)$, and a blue spot $\left(\mathrm{R}_{\mathrm{F}}=0.86\right)$ not detected elsewhere (Figure 1). The flavonoid profile observed here in leaf extracts of in vitro plants of $P$. alata and P. suberosa was similar to the observed by Birk et al. (2005) in extracts of aerial parts of in vivo-grown plants of these two species.

Although flavonoids are more frequently reported in the genus, saponins could also be associated with some Passiflora species. Passiflora alata presents saponins as its major phytoconstituent, and five saponins have already been isolated and identified from leaves of this species, one steroidal and four triterpenes (Reginatto et al. 2001). In addition, Simão et al. (2016) have recently described the presence of saponins in different plant materials of $P$. pohlii. In this work, saponins were detected in extracts from the four studied species, characterized by orange, purple and dark spots (Figure 2). Leaves of P. suberosa, P. foetida, as well as roots of $P$. alata presented similar purple spots $\left(\mathrm{R}_{\mathrm{F}}=0.48\right)$, which suggests that they might be the same substance. Four dark spots with the same color and $\mathrm{R}_{\mathrm{F}}(0.34)$ were observed in root extracts of the four species. Roots of P. alata, $P$.

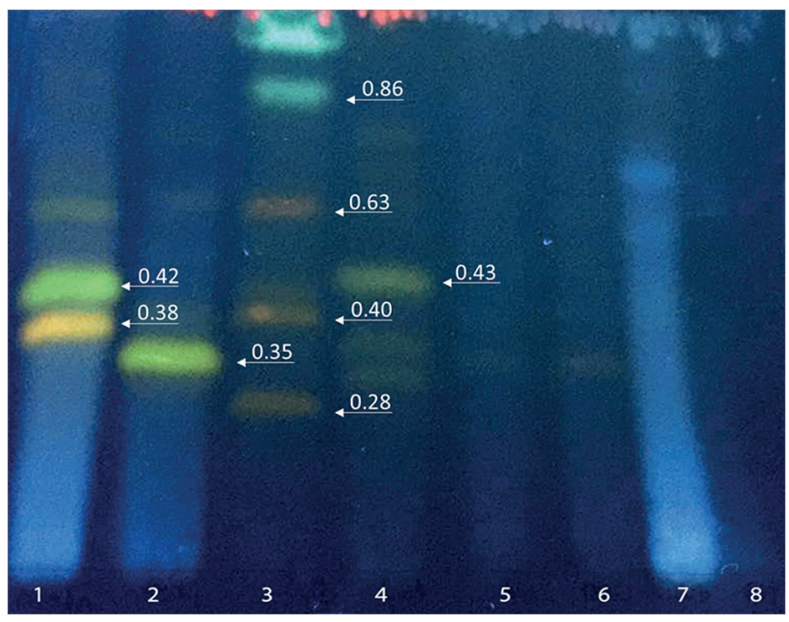

Figure 1 - TLC plate for the identification of flavonoids in the extracts from in vitro derived materials of four Passiflora species. 1-4 Leaves of P. alata (1), P. pohlii (2), P. suberosa (3), P. foetida (4). 5-8 Roots of P. alata (5), P. pohlii (6), P. suberosa (7), P. foetida (8). Mobile phase: AcOEt:formic acid:AcOH: $\mathrm{H}_{2} \mathrm{O}(100: 11: 11: 26, \mathrm{v} / \mathrm{v})$. Visualization: NP/PEG $4000 / \mathrm{UV}_{365 \mathrm{~nm}}$.

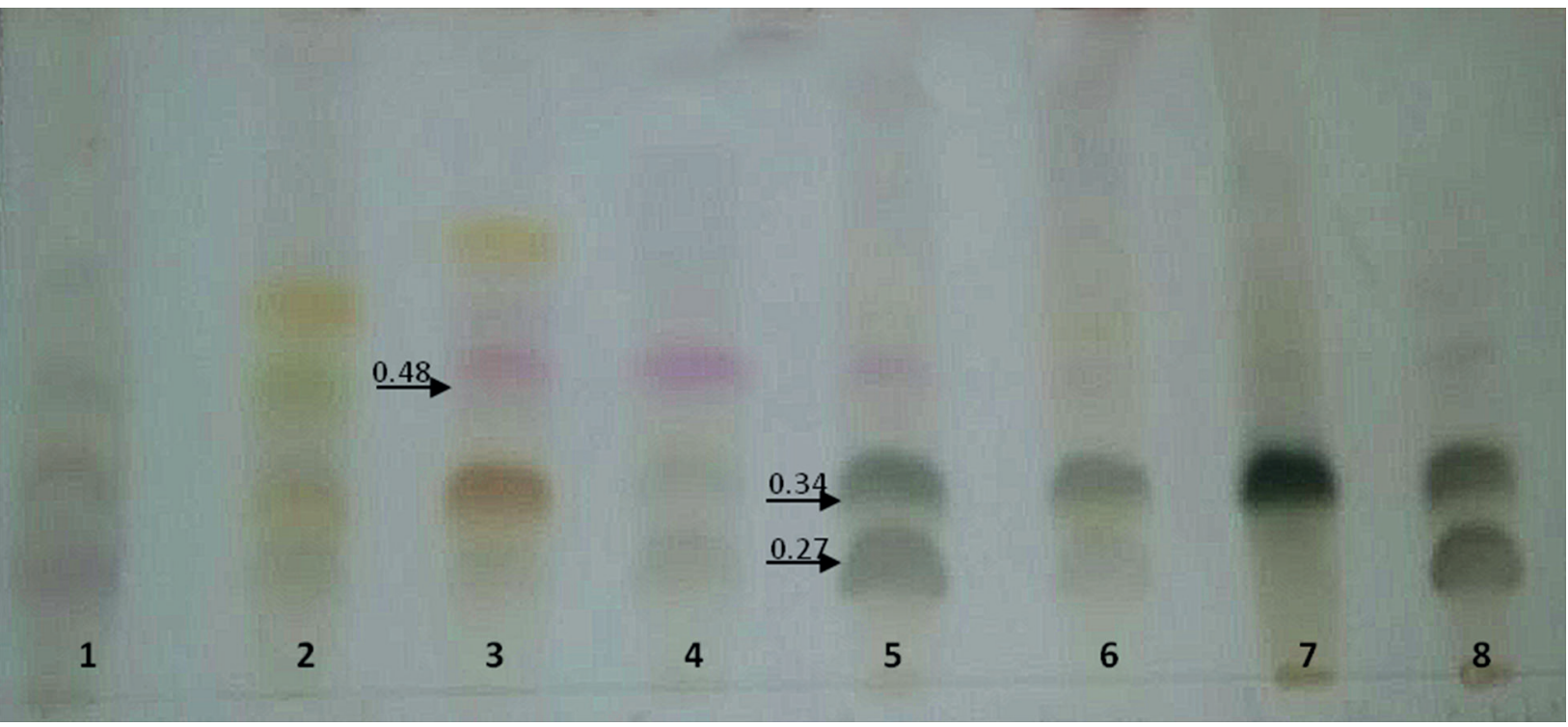

Figure 2 - TLC plate for the identification of saponins in the extracts from in vitro derived materials of four Passiflora species. 1-4 Leaves of P. alata (1), P. pohlii (2), P. suberosa (3), P. foetida (4). 5-8 Roots of P. alata (5), P. pohlii (6), P. suberosa (7), P. foetida (8). Mobile phase: $\mathrm{CHCl}_{3}: \mathrm{AcOH}: \mathrm{MeOH}: \mathrm{H}_{2} \mathrm{O}(60: 32: 12: 8, \mathrm{v} / \mathrm{v})$. Visualization: anisaldehyde- $\mathrm{H}_{2} \mathrm{SO}_{4} /$ heating $\left(100{ }^{\circ} \mathrm{C}\right)$. 
pohlii and $P$. foetida also presented grey spots, with the same $\mathrm{R}_{\mathrm{F}}(0.27)$.

The antibacterial potential of crude extracts from in vitro derived leaves and roots was also evaluated in this work. Extracts from leaves and roots of $P$. alata and $P$. foetida showed a selective inhibitory activity on the growth of only two strains, namely Bacillus thuringiensis (ATCC 33679) and Streptococcus pyogenes (ATCC 8668). Root extracts of $P$. alata also reduced the growth of Pseudomonas aeruginosa (ATCC 27853). On the other hand, an increased growth was observed in almost all strains tested in response to extracts from in vitro derived leaves of $P$. alata and leaves and roots of $P$. foetida, when compared to the control (Table II).
Leaves and roots of $P$. pohlii showed an increase of growth of all tested strains, except for Streptococcus pyogenes, which presented similar growth as the control plate. In contrast, $P$. suberosa extracts did not alter the growth of the 20 strains tested (Table II).

Based on these results, extracts from $P$. alata and $P$. foetida were tested for $\mathrm{IC}_{50}, \mathrm{MIC}$ and MBC for the inhibition of $B$. thuringiensis and $S$. pyogenes growth and the results are shown in Table III. Root extracts of $P$. alata showed the lowest $\mathrm{IC}_{50}$ for both strains when compared to the other three extracts tested, with $28.98 \mu \mathrm{g} \mathrm{mL}^{-1}$ for $S$. pyogenes and $9.08 \mu \mathrm{g} \mathrm{mL}^{-1}$ for $B$. thuringiensis. Root extracts of $P$. alata and $P$. foetida also presented the lowest MIC for both strains, which were less than $100 \mu \mathrm{g}$

TABLE II

Evaluation of the antibacterial activity of crude extracts $\left(1000 \mu \mathrm{g} \cdot \mathrm{mL}^{-1}\right)$ from in vitro-derived materials of four Passiflora species using the macrodilution method.

\begin{tabular}{|c|c|c|c|c|c|c|c|c|c|}
\hline & \multirow{2}{*}{ Strains } & \multicolumn{2}{|c|}{ P. alata } & \multicolumn{2}{|c|}{ P. foetida } & \multicolumn{2}{|c|}{ P. pohlii } & \multicolumn{2}{|c|}{ P. suberosa } \\
\hline & & Leaves & Roots & Leaves & Roots & Leaves & Roots & Leaves & Roots \\
\hline \multirow{6}{*}{ Gram-positive } & B. thuringiensis & IN & IN & IN & IN & I & I & - & - \\
\hline & E. faecalis & I & - & I & I & I & I & - & - \\
\hline & S. aureus & I & - & I & I & I & I & - & - \\
\hline & S. simulans & I & - & I & I & I & I & - & - \\
\hline & S. saprophyticus & I & - & I & I & I & I & - & - \\
\hline & S. pyogenes & IN & IN & IN & IN & - & - & - & - \\
\hline \multirow{14}{*}{ Gram-negative } & A. caviae & I & - & I & I & I & I & - & - \\
\hline & A. hydrophila & I & - & - & I & I & I & - & - \\
\hline & C. freundii & I & - & I & I & I & I & - & - \\
\hline & E. coli $(17-2)$ & I & - & I & I & I & I & - & - \\
\hline & E. coli (ATCC 25922) & I & - & I & I & I & I & - & - \\
\hline & E. coli (ATCC 35218) & I & - & I & I & I & I & - & - \\
\hline & E. coli $\mathrm{K}-12$ (HB 101) & I & - & I & I & I & I & - & - \\
\hline & E. coli $\mathrm{K}-12$ (C600) & I & - & I & I & I & I & - & - \\
\hline & E. coli (EAEC 042) & I & - & - & I & I & I & - & - \\
\hline & K. pneumoniae & I & - & - & I & I & I & - & - \\
\hline & P. aeruginosa & - & $\mathrm{RD}$ & - & - & I & I & - & - \\
\hline & S. typhimurium & I & - & I & I & I & I & - & - \\
\hline & S. marcescens & I & - & I & I & I & I & - & - \\
\hline & S. sonnei & I & - & I & I & I & I & - & - \\
\hline
\end{tabular}

$\mathrm{I}=$ increase $\mathrm{RD}=$ reduction; $\mathrm{IN}=$ inhibition; Trace $=$ similar growth in the control MHA. 
TABLE III

Inhibitory concentration of $50 \%$ of the population $\left(\mathrm{IC}_{50}\right)$, minimum inhibitory concentration (MIC) and minimum bactericidal concentration (MBC) values $\left(\mu \mathrm{g} \cdot \mathrm{mL}^{-1}\right)$ of crude extracts of leaves and roots excised from in vitro-grown plants of $P$. alata and $P$. foetida.

\begin{tabular}{|c|c|c|c|c|c|c|c|}
\hline \multirow{2}{*}{\multicolumn{2}{|c|}{$\begin{array}{c}\text { Extracts } \\
\mathrm{IC}_{50}\end{array}$}} & \multicolumn{3}{|c|}{ Streptococcus pyogenes } & \multicolumn{3}{|c|}{ Bacillus thuringiensis } \\
\hline & & \multirow{2}{*}{$\begin{array}{c}\text { MIC } \\
488\end{array}$} & \multirow{2}{*}{$\begin{array}{l}\text { MBC } \\
>750\end{array}$} & \multirow{2}{*}{$\begin{array}{l}\mathbf{I C}_{\mathbf{5 0}} \\
1000\end{array}$} & \multirow{2}{*}{$\begin{array}{c}\text { MIC } \\
75.67\end{array}$} & \multirow{2}{*}{$\begin{array}{l}\text { MBC } \\
>250\end{array}$} & \multirow[b]{2}{*}{$>1000$} \\
\hline & Leaves & & & & & & \\
\hline 1. аica & Roots & 28.98 & $>100$ & 500 & 9.08 & $>100$ & 750 \\
\hline \multirow{2}{*}{ P. foetida } & Leaves & 104.74 & $>250$ & $>500$ & 75.3 & $>250$ & $>500$ \\
\hline & Roots & 36.89 & $>100$ & $>250$ & 37.51 & $>100$ & 500 \\
\hline
\end{tabular}

$\mathrm{mL}^{-1}$. The best MBC for $S$. pyogenes was displayed by roots extracts of $P$. foetida, with values under $250 \mu \mathrm{g} \mathrm{mL}^{-1}$. For B. thuringiensis, the lowest MBC was displayed by leaf extracts of $P$. foetida, with values under $500 \mu \mathrm{g} \mathrm{mL}^{-1}$ (Table III).

Previous reports described antibacterial activity of extracts from different plant materials of in vivo-grown plants of $P$. foetida against both Gram-positive and Gram-negative strains. Bendini et al. (2006) reported high antimicrobial activity of leaf extracts of $P$. foetida. Mohanasundari et al. (2007) observed the effect of the extracts from leaves and fruits against Pseudomonas putida, Vibrio cholerae, Shigellaflexneri and Streptococcus pyogenes using the well-in-agar method. Baby et al. (2010) used the Kirby-Bauer disc diffusion method to test the effect of root extracts against Staphylococcus epidermidis, Bacillus subtilis, Klebsiella pneumoniae, Pseudomonas aeruginosa and Escherichia coli. On the contrary to the observed in this work, these studies reported better antibacterial activity against Gram-negative strains.

Although the role played by the secondary metabolites is not yet fully understood, their presence in plant extracts has already been associated with antibacterial potential (Bukke et al. 2015, Dzotam et al. 2016). In the genus Passiflora, the production of total phenols, flavonoids and tannins, as well as the evaluation of the antibacterial potential of leaf extracts of $P$. alata prepared with different solvents was reported by Vasic et al. (2012). They observed that the ethyl acetate extract showed stronger antibacterial activity when compared to the other extracts tested, especially against Gram-positive strains. However, they detected low levels of phenols and flavonoids in this extract, suggesting that the antibacterial activity was not related to these phytoconstituents. Johnson et al. (2008) also attributed the high inhibition rates of chloroform extracts of callus of $P$. edulis against Staphylococcus aureus, Pseudomonas aeruginosa, Klebsiella aerogenes, Aeromonas spp., Serratia and Escherichia coli to the presence of a diversity of compounds, including saponins, tannins, triterpenoids, alkaloids and flavonoids.

To our knowledge, this is the first report on the antibacterial potential of in vitro derived materials of P. alata, P. foetida, P. pohlii and P. suberosa. Although further studies are required aiming at the isolation and identification of the flavonoids and saponins observed in the extracts of the four studied species, the solid inhibiting effect on the growth of two bacterial strains, as seen by the results of MIC and MBC analyses, may be associated with the presence of these compounds in the extracts of P. alata and P. foetida.

\section{ACKNOWLEDGMENTS}

The authors acknowledge Fundação Carlos Chagas Filho de Amparo à Pesquisa do Estado do Rio de Janeiro (FAPERJ) and Conselho Nacional de Desenvolvimento Científico e Tecnológico (CNPq) 
for the financial support, scholarships and research fellowships.

\section{REFERENCES}

ANTOGNONI F, ZHENG S, PAGNUCCO C, BARALDI R, POLI F AND BIONDI S. 2007. Induction of flavonoid production by UV-B radiation in Passiflora quadrangularis callus cultures. Fitoterapia 78: 345-352.

BABY E, BALASUBRAMANIAM A, MANIVANNAN R, JOSE J AND SENTHILKUMAR N. 2010. Antibacterial activity of methanolic root extract of Passiflora foetida Linn. J Pharmac Sci Res 2: 38-40.

BARBOZA TJS, FERREIRA AF, IGNACIO ACPR AND ALBARELLO N. 2015. Antimicrobial activity of Anonna mucosa (Jacq.) grown in vivo and obtained by in vitro culture. Braz J Microbiol 46: 785-789.

BAX R, MULLAN N AND VERHOEF J. 2000. The millennium bugs - The need for and development of new antibacterials. Int J Antimicrob Ag 1: 51-59.

BENDINI A, CERRETANI L, PIZZOLANTE L, TOSCHI TG, GUZZO F, CEOLDO S, MARCONI AM, ANDREETTA F AND LEVI M. 2006. Phenol content related to antioxidant and antimicrobial activities of Passiflora spp. extracts. Eur Food Res Technol 223: 102109.

BIRK CD, PROVENSI G, GOSMANN G, REGINATTO FH AND SCHENKEL EP. 2005. TLC fingerprint of flavonoids and saponins from Passiflora species. J Liq Chrom Rel Technol 28: 2285-2291.

BRAZILIAN PHARMACOPOEIA. 2010. $5^{\text {a }}$ ed., Brasília: ANVISA - Agência Nacional de Vigilância Sanitária.

BUKKE AN, HADI FN AND PRODUTUR CS. 2015. Comparative study of in vitro antibacterial activity of leaves, bark, heart wood and seed extracts of Caesalpinia sappan L. Asian Pac J Trop Dis 5: 903-907.

COLOMEU TC, FIGUEIREDO D, CAZARIN CBB, SCHUMACHER NSG, MARÓSTICA JR MR, MELETTI LMM AND ZOLLNER RL. 2014. Antioxidant and anti-diabetic potential of Passiflora alata Curtis aqueous leaves extract in type 1 diabetes mellitus (NOD-mice). Int Immunopharmacol 18: 106-115.

DHAWAN K, DHAWAN S AND SHARMA A. 2004. Passiflora: A review update. J Ethnopharmacol 94: 1-23.

DZOTAM JK, TOUANI FK AND KUETE V. 2016. Antibacterial activities of the methanol extracts of Canarium schweinfurthii and four other Cameroonian dietary plants against multi-drug resistant Gram-negative bacteria. Saudi J Biol Sci 23: 565-570.

FRACCAROLI M, NICOLETTI S, MALTESE F, CHOI YH, LEVI M AND VERPOORTE R. 2008. Pre-analytical method for metabolic profiling of plant cell cultures of Passiflora garckei. Biotechnol Lett 30: 2031-2036.
GARCIA R, PACHECO G, FALCÃO E, BORGES G AND MANSUR E. 2011. Influence of type of explant, plant growth regulators, salt composition of basal medium, and light on callogenesis and regeneration in Passiflora suberosa L. (Passifloraceae). Plant Cell Tiss Org Cult 106: 47-54.

GARDNER DE. 1989. Pathogenicity of Fusarium oxysporum f. sp. passiflorae to Banana Poka and Other Passiflora spp. in Hawaii. Plant Dis 73: 476-478.

GOSMANN G, PROVENSI G, COMUNELLO LN AND RATES SMK. 2011. Chemical studies and pharmacological activities of Passiflora L. species (Passifloraceae). Rev Bras Bioc 9: 88-99.

INGALE AG AND HIVRALE AU. 2010. Pharmacological studies of Passiflora sp. and their bioactive compounds. Afr J Plant Sci 4: 417-426.

JOHNSON M, MARIDASS M AND IRUDAYARAJ V. 2008. Preliminary phytochemical and antibacterial studies on Passiflora edulis. Ethnobot Leaflets 12: 425-432.

JUNQUEIRA NTV, BRAGA MF, FALEIRO FG, PEIXOTO JR AND BERNACCI LC. 2005. Potencial de espécies silvestres de maracujazeiro como fonte de resistência a doenças. In: Faleiro FG, Junqueira NTV and Braga MF (Eds.), Passionfruit: germplasm and breeding, Planaltina, DF: Embrapa Cerrados, Brasil, p. 81-108.

LUGATO D, SIMÃO MJ, GARCIA R, MANSUR E AND PACHECO G. 2014. Determination of antioxidant activity and phenolic content of extracts from in vivo plants and in vitro materials of Passiflora alata Curtis. Plant Cell Tiss Org Cult 118: 339-346.

MERHY TSM, VIANNA MG, GARCIA R, PACHECO G AND MANSUR E. 2014. Cryopreservation of Passiflora pohlii nodal segments and assessment of genetic stability of regenerated plants. Cryo-Lett 35: 204-215.

MILLER LG. 1998. Herbal medicinals: selected clinical considerations focusing on known or potential drug-herb interactions. Arch Int Med 158: 2200-2211.

MOHANASUNDARI C, NATARAJAN D, SRINIVASAN K, UMAMAHESWARI S AND RAMACHANDRAN A. 2007. Antibacterial properties of Passiflora foetida L. - a common exotic medicinal plant. J Biotechnol 6: 26502653.

MONTEFUSCO-PEREIRA CV, CARVALHO MJ, BOLETI APA, TEIXEIRA LS, MATOS HR AND LIMA ES. 2013. Antioxidant, anti-inflammatory, and hypoglycemic effects of the leaf extract from Passiflora nitida Kunth. Appl Biochem Biotech 170: 1367-1378.

MONTEIRO ACBA, HIGASHI EN, GONÇALVES AN AND RODRIGUEZ APM. 2000. A novel approach for the definition of the inorganic medium components for micropropagation of yellow passionfruit (Passiflora edulis Sims. f. flavicarpa Deg.). In Vitro Cell Dev Biol - Plant 36: 527-531. 
PACHECO G, GARCIA R, LUGATO D, VIANNA M AND MANSUR E. 2012. Plant regeneration, callus induction and establishment of cell suspension cultures of Passiflora alata Curtis. Sci Horticult 144: 42-47.

PAN L, BLANCO EJC AND KINGHORN AD. 2009. Plantderived natural products as leads for drug discovery. In: Osbourn AE and Lanzotti V (Eds), Plant-Derived Natural Products, Springer US, New York, USA, p. 547-567.

RAMAIYA SD, BUJANG JS AND ZAKARIA MH. 2014. Assessment of total phenolic, antioxidant, and antibacterial activities of Passiflora species. Sci World J 2014: 1-10.

RAZIA M AND BEULAH SIVARAMAKRISHAN S. 2014. Phytochemical, GC-MS, FT-IR analysis and antibacterial activity of Passiflora edulis of Kodaikanal region of Tamilnadu. World J Pharm Pharm Sci 3: 435441.

REGINATTO FH, KAUFFMAN C, SCHRIPSEMA J, GUILLAUME D, GOSMANN G AND SCHENKEL EP. 2001. Steroidal and triterpenoidal glucosides from Passiflora alata. J Braz Chem Soc 12: 32-36.

RIPA FA, HAQUE M, NAHAR L AND ISLAM MM. 2009. Antibacterial, cytotoxic and antioxidant activity of Passiflora edulis Sims. Eur J Sci Res 31: 592-598.

SIMÃO MJ, FONSECA E, GARCIA R, MANSUR E AND PACHECO G. 2016. Effects of auxins and different culture systems on the adventitious root development of Passiflora pohlii Mast. and their ability to produce antioxidant compounds. Plant Cell Tiss Org Cult 124: 419430.

SOBERÓN JR, SGARIGLIA MA, SAMPIETRO DA, QUIROGA EM AND VATTUONE MA. 2007. Antibacterial activity of plant extracts from northwestern Argentina. J Appl Microbiol 102: 1450-1461.

SUBRAMANI V, KAMARAJ M, SENTHIL K, RAMACHANDRAN B, JEROME JJ AND PREMA D. 2014. Studies on phytochemical properties and antimicrobial activities of Passiflora foetida L. and Ficus retusa L. J Res Plant Sci 3: 249-254.

ULMER T AND MACDOUGAL JM. 2004. Passiflora: passionflowers of the world. Portland-Cambridge: Timber Press, $430 \mathrm{p}$.

VASIC SM, STEFANOVIC OD, LICINA BZ, RADOJEVIC ID AND COMIC LR. 2012. Biological activities of extracts from cultivated Granadilla Passiflora alata. EXCLI J 11: 208-218.

WAGNER H AND BLADT S. 2001. Plant Drug Analysis: A Thin Layer Chromatography Atlas. Berlin: Springer, 384 p.

WILSON SA AND ROBERTS SC. 2012. Recent advances towards development and commercialization of plant cell culture processes for the synthesis of biomolecules. Plant Biotechnol J 10: 249-268. 